\title{
An Integrated Conceptual Framework for ICT-based Market Information Source Adoption among Smallholder Farmers
}

\author{
Nwafor, Christopher Ugochukwu \\ manchrizzo@hotmail.com \\ Central University of Technology, Free State, South Africa.
}

\begin{abstract}
:
The importance of ICTs for dissemination of information to farmers has been verified by extension practitioners, information and communication scholars, policy makers and development agencies. Information related to new seed varieties, production technologies, livestock breeds, vaccines, including weed and pest control, as well as relevant market information is constantly required by smallholder farmers. The identification of specific attributes among smallholder farmers which contributes to their adoption of a proposed ICT-based information source provides an important tool for developing interventions which address the information needs of farmers. Using a literature survey methodology, pertinent studies related to adoption of ICTs, farmers' information source usage and relevant frameworks were identified, including applicable theories and models in technology adoption and information behaviour. In the proposed framework, the socio-economic characteristics of smallholder farmers were posited as key variables influencing smallholder farmers, within a farming system, to adopt ICT-based information sources. The framework contributes to discern the prospects of adopting ICT-based information sources by individual farmers within a farming system, and may also envisage other related welfare outcomes and market participation pathways among smallholder farmers. The review also addresses the paucity of conceptual discourse, while contributing to a growing pool of research on ICT in African agriculture.
\end{abstract}

Keywords: information source, smallholder farmers, ICTs, adoption, conceptual framework, sub-Sahara Africa

\section{INTRODUCTION}

Information sources are vital and considered a pre-requisite for objective decision-making. It is agreed that information sources must be accurate, provide relevant and current information for it to be used frequently (Adereti, Fapojuwo and Onasanya, 2006; Kapoor, 2015). Other characteristics of a good information source include its cost-effectiveness, trustworthiness, usability, exhaustiveness and aggregation level (Acheampong et al., 2017). Information sources are important as they have contributory linkages to the utilization of information by farmers (Fawole, 2006), and determines whether the information is acted on or not. An understanding of preferred information source(s) among any group of farmers is pertinent in designing specific and targeted interventions (Babu et al., 2012), and it is for this reason that research has focussed on the source(s) of information available to smallholder farmers, 
especially in Africa (e.g. Okello, Al-Hassan and Okello, 2010; Oladele, 2011; Katengeza, 2012; Magesa, Michael and Ko, 2015; Mssofe and Ngulube, 2017; Kante, Oboko and Chekpen, 2019)

The term 'information source' may be ambiguous, as it may refer to a medium, a tool, a channel, carrier or even a personality or individual. The information source contains information or is the medium through which information or knowledge is shared (Bitso, 2012). According to Koyenikan (2011), information sources may be formal or informal, highlighting the diversity of information sources. It is pertinent to point out that an information source provides or links the information seeker with needed information. In whatever manner it is framed, information sources should meet the information needs of different categories of users. Research indicates that smallholder farmers rely on informal and inter-personal sources of information (see Adio et al., 2016; Msoffe and Ngulube, 2017; Sanusi et al., 2018), and pointed out their strong reliance on neighbours and other farmers. Such sources are also multiple, which Mittal and Mehar (2015) espoused as being complementary, and further reported that farmers characteristics are correlated with their perceptions of the sources of information they consider valuable.

The utility of ICTs for disseminating information to users is prominent in the literature, and among scholars there is an emerging consensus regarding the applicability of ICT tools for improving access to market information among smallholder farmers in developing countries (see Katengeza, Okello and Mensah, 2011; Kiiza and Penderson, 2012; Ochieng, Okello and Otieno, 2013). The dependence of smallholder farmers on inter-personal sources, and their lack of access to information have been recognized as a major constraint that continues to limit their participation in markets. Due to this lack of market information, smallholder farmers face disadvantages and exploitation in their interaction with better informed market players (Magesa et al., 2015).

Consequently, there are interventions aimed at enhanced use of ICT-based tools for providing market information to smallholder farmers in many developing countries. This is intended to be achieved by linking farmers to markets using ICTs, which Zoltner and Steffen (2013), Torero (2011), and Prakash (2008) assured would reduce information asymmetry and transaction costs, minimize risks and other disadvantages associated with market transactions among smallholder farmers. In addition, the use of ICT-enabled market information sources is posited to increase market transparency by providing current market information, while at the 
same time, improving income and other welfare outcomes (Katengesa, 2012; Martey, 2014; Katengesa, Okello, Mensah and Jambo, 2014). Proponents of ICT-enabled market information sources such as Gwaka (2017) and Payne (2011), envisage ubiquitous information systems, capable of widespread distribution of market information and resulting in increased accessibility and participation of smallholder farmers in markets.

This review therefore aimed at outlining a conceptual framework which consolidates the factors leading to ICT-based information source adoption among smallholder farmers.

\section{METHODOLOGY}

The conceptual analysis and literature review approach was used. The review involved analysis of published resources from a search of available literature on the use of ICT-based sources among smallholder farmers, identification of relevant frameworks and empirical results from related studies. Using the EBSCO-host retrieval database, a basic search using relevant keywords produced a huge number of entries, which were further reduced by application of limiters, such as relevance, publication period and peer-reviewed journals.

\section{REVIEW OF RELEVANT LITERATURE}

Agriculture is, without doubt, an information sensitive sector (Deloitte, 2012), and Opara (2008) asserted that information use in agriculture has increasingly become important for effective decision making by farmers. There is a viewpoint which suggests that information is a public good that should be made widely and freely available (Pimentel and Franscisco, 2009; Ferris, Engoru and Kaganzi, 2008), therefore, farmers need to be connected to sources where they derive appropriate information (Manfre and Nordehn, 2014). Modern and widely available information and communication technologies (ICTs) are able to deliver relevant and timely information, facilitating informed decisions for utilising resources in the most productive and efficient mode. It is on this premise that Oladele (2011) declared that ICTs have become the gateway for agricultural information, due to the immensely optimistic perception among relevant stakeholders, such as extension agents, researchers and farmers, regarding its role. Additionally, these ICT tools have the potential to not only transform agricultural systems, but also ensure prosperity of farm enterprises (Gwaka, 2017). Generally speaking, farmers are a group of active information-seekers and users, especially for their production and marketing decisions. There is scant literature on the information-source adoption attributes of farmers and its contribution to their decision-making processes (Just et al., 2002; McBride and Daberkow, 
2003). Available studies primarily focus on the adoption of technology by farmers and not on the information sources influencing adoption (Velandia et al., 2009).

Impressive growth in the application of information and communication technologies for marketing, production and services is acclaimed in the literature. The efficiency gains generated by farmers through the use of ICTs and subsequent transformations in agri-food production and processing systems have been noted (GODAN, 2018). The utility of ICTs in agricultural marketing and production value-chains have been highlighted by the World Bank (2011), and according to Tembo and Maumbe (2010), ICTs have become invaluable to the success of commercially oriented agricultural production. The efficacy of ICTs and its linkage to smallholder market participation is reiterated by Sibande, Barley and Davidova (2015), asserting that the receipt of market information from ICT-based media positively influenced market participation among smallholder farmers.

The imposing digital divide faced by smallholder farmers, especially in rural sub-Sahara African communities is a major cause for concern. This is because farmers lacking access to ICTs may experience digital poverty, increasing their risks which may also prevent them from adopting additional agriculture-based technologies (Okello et al. 2014; Freeman and Mubichi, 2017). All of which reinforces their vulnerability to the acclaimed poverty trap (Barrett and Carter, 2013). This poverty limits access to information due to the costs involved in gathering information, and the remote rural environment where smallholder farmers reside is characterised by unequal and inequitable distribution of information (Magesa et al., 2014; Svensson and Yanagizawa, 2009). Khalil-Moghaddam and Khalia-Abadi (2013) declared that the identification of factors which foster adoption of ICTs is among the important challenges for alleviating a potential digital divide. They argued that availability- regarded as the existence of a system, worked towards reinforcing adoption attributes in the population and also affirmed the influence of certain socio-economic variables in the adoption of ICTs.

Research shows that individual characteristics are important indicators for technology adoption (Ali and Kumar, 2011; Oluwatayo, 2014), and to effectively incorporate ICTs, both the cultural context and specific characteristics of both adaptors and innovations must be taken into consideration (Kyem 2012). Individual attributes also influence the need for information, as well as the capacity to obtain and utilize such information (Israel and Wilson, 2006). While developing a model for computer uptake and use among farmers, Alvarez and Nuthall (2006) averred that farmer attributes such as enterprise objectives, personality, education, skills, 
current information management processes, and learning style were associated with their use of ICT-based information systems. Velandia et al. (2009) also posited that farmer's socioeconomic and demographic factors impact their preference regarding information-source usage.

This corroborates the position of Just et al. (2002), that different human capital attributes favour the use of different information sources. It also fits the narrative espoused within the economic approaches regarding decision-making (Agrilink, 2017), which assumes that decision-making processes are hinged on an internalized comparative analysis by the concerned person(s). Hill (2009) earlier reported that farmers, as individuals, have their preferred information sources which they utilise depending on the type of information sought. However, the reliance on the economic approach alone for decision-making ignores the complexities involved; as economic decisions are often embedded in specific technological pathways, institutional frameworks and socio-cognitive norms.

Due to this, social psychology theories such as Ajzen's $(2005,2011)$ Theory of Planned Behaviour which linked social norms and practical limitations, have found increased application in explaining farmers decision-making, and, in this instance, their informationseeking behaviour. In the context of smallholder farmers' decision-making, the theory suggests that the decision of the farmer to switch information sources, aimed at meeting a specific objective, is actively planned (Sutherland, 2010). The farmer has a clear motive in considering using the information source, thinks of the practicality of using the information source, and more importantly, the social implications of utilizing the proposed information source; which in this instance, is akin to a planned behaviour.

In their study of precision technology adoption among farmers, Velandia et al. (2009) postulated that farmers must make a decision regarding which information source to use from among the array of available sources. The importance of delineating information sources is highlighted by Adegbola and Gardebroek (2007), who found group differences in adoption behaviour between farmers informed by extension agents and those informed by fellow farmers. Isaya, Agunga and Sanga (2016) also emphasised the importance of understanding how rural farmers source their information; this, in their view, enables the dissemination of effective communication using accessible channels to the targeted audience.

ICTs provide an effective means for providing information to farmers, notwithstanding the associated challenges due to its use, reported in Benard, Dulle and Lamtane (2019). Waqas et 
al. (2015) reported how socio-economic characteristics of farmers influenced their use of information sources, and ultimately contributed to the adoption of relevant production technologies. Related to this, Somers and Stapleton (2013) proposed new integral systems framework of e-agricultural adoption aimed at initiating new avenues for research, theory and practice, which ultimately informs policy related to e-readiness among rural communities. Following Valendia et al. (2009), the empirical approaches adopted suggest that the decision to use a particular information source is independent across information sources.

The need for models or frameworks that enhance our understanding of information sources preferred by farmers and how ICTs are linked must be considered an on-going endeavour. This is as a result of rapid changes in how information is generated and used. Such frameworks help with, developing new systems for information dissemination, addressing the need for understanding the target community before propagation of information (Msoffe and Ngulube, 2016), predicting the information-seeking behaviour of farmers (Mahindarathne and Min, 2018), placing emphasis on socio-economic factors in the technology adoption decisions (Lubua and Kyobe, 2019), or establishing factors that influence increased adoption of farm input and their relationships (Kante et al., 2019).

By proposing an integrated conceptual framework of ICT-based information source adoption, this paper tackles this requirement for knowledge generation in information source usage; and how the attributes of smallholder farmers align with their adoption of information communication technology sources. The model could help elucidate why farmers choose one information source, or a combination of sources, as against others, for obtaining their market information, and ultimately assist information providers to better utilize ICT-based tools to meet farmers market information needs. The proposed framework could- for instance, guide the design of communication strategies for extension and advisory services to farmers, as well as provide a general guide for other professionals involved in developing relevant interventions.

\section{THEORETICAL UNDERPINNINGS}

The review is anchored and draws from three widely used technology acceptance theories in the literature. These theories are the Technology Acceptance Model (TAM), the Unified Theory of Acceptance and Use of Technology (UTAUT) and the Diffusion of Innovation (DOI) theory. Technology Acceptance Models derive from the Theory of Reason Action, which 
elucidates how users adopt a technology, has been extensively applied in the explication of ICT usage in different sectors.

Rogers and Shoemaker's (1971) seminal SMCRE model which described the processes involved in the spread of an innovation through channels, over time and among members of a social system, provided an acknowledgment of the important relationship between the source of a message and effect on the receiver. Utilizing an adapted model, the relationships indicates the important role played by the channel through which the message is sent and the feedback provided by the receiver.

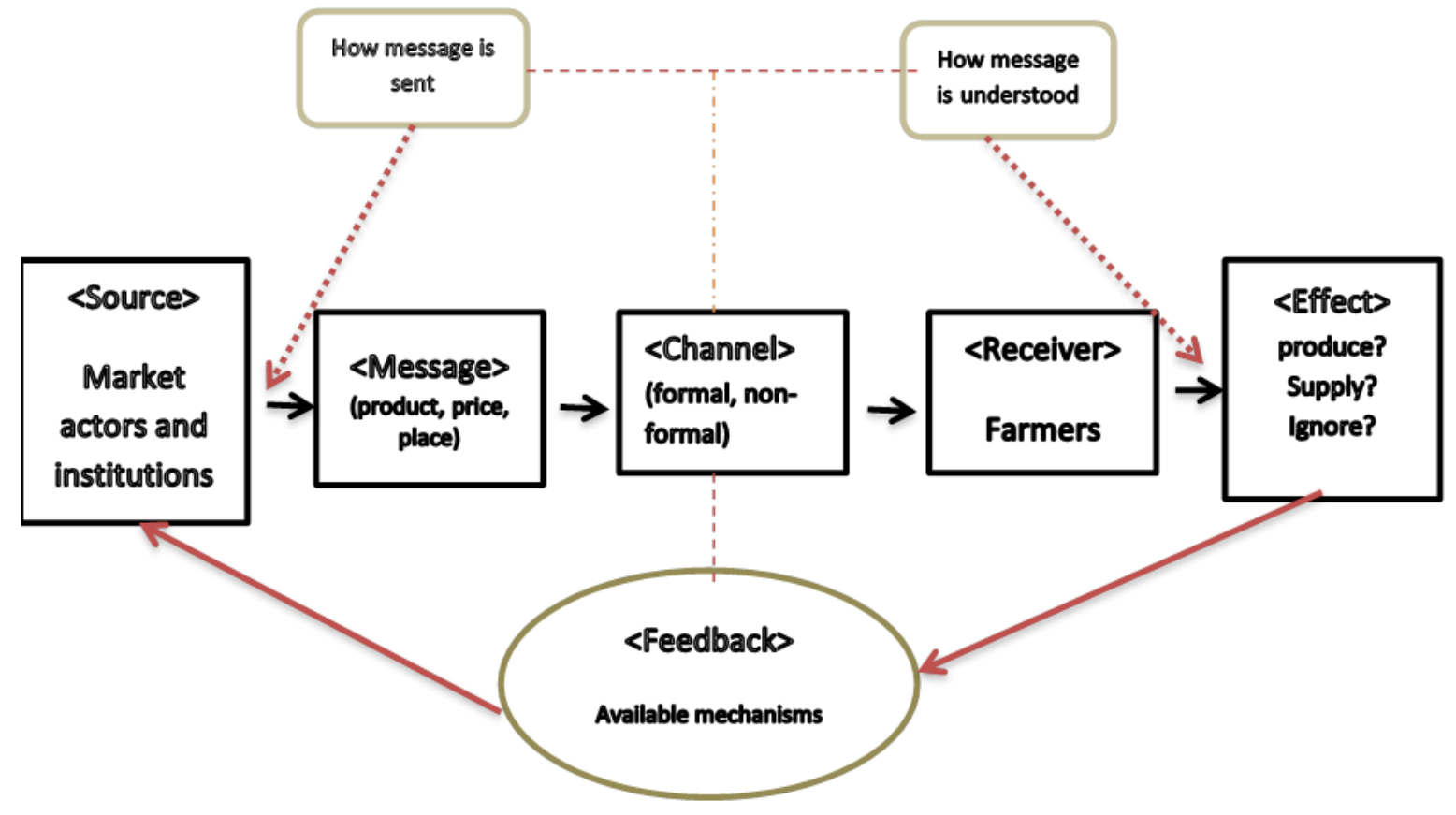

Figure 1. Farmers Source-Message-Channel-Receiver-Effect Model (Adapted from: Rogers and Schoemaker, 1971).

The model shown in Figure 1, indicates that a source (S), such as market actors, may originate a message (M) highlighting specific requirements of product, price and place. These messages are communicated using available channels (C), which may include ICT-enhanced tools, often used interchangeably when referring to information sources in the literature (Msoffe and Ngulube, 2017; Osei et al., 2016). These channels (sources) are considered worthy of researching to provide insight on how farmers receive (R) information (Isaya et al., 2016), and in this instance, the effect $(\mathrm{E})$ is considered as their action or feedback to the market actors. 
The Technology Acceptance Model (TAM) outlined in Davis et al. (1989) as adapted from the Theory of Reasoned Action, is an information systems theory which models technology acceptance and use. Its two most important pillars are the individuals' perceived usefulness and ease of use ( $\mathrm{Li}, 2010)$. These two beliefs then lead to individual intention and actual behaviour. The focus of the theory is on the individual, whose relevant features can be identified using their personal characteristics. For this reason, Kim and Crowston (2011) have emphasized the importance of the individual user perspective in ICT adoption research, and encouraged Information Systems scholars to identify factors that influence individual users' adoption and use of ICTs.

The Unified Theory of Acceptance and Use of Technology (UTAUT) integrates the elements from eight technology acceptance models (Venkatesh et al., 2003), and is widely accepted and validated for technology adoption, but has been variously criticised for grouping and labelling a variety of items to represent single constructs. This representation of a single construct by different variables is problematic. For clarity and significance, Raaij and Schepers (2008) have argued for the inclusion of single variables that, in their view, moderate the key relationships within the model. These variables proposed to yield more significant coefficients, are primarily composed of personal features such as gender, age, and experience.

The Diffusion of Innovation (DOI) Theory of Rogers (1995), when used to study the adoption or use of ICT services is considered as a Technology Acceptance Model; emphasised in many studies including MacVaugh and Schiavone (2010), and Woosley and Ashia (2011). In line with this, Simin and Jankovic (2014) professed that the theory attempts to predict the behaviour of individuals and social groups, considering their individual characteristics and social relations, among others. Hence, Kapoor et al. (2013) reported that many researchers have utilized the theory to aid understanding of technology adoption. An advantage of the Diffusion of Innovation Theory, as asserted by Ituma-Aleke and Egwu (2014), is the provision of a contextual set driving the acceptance of a technological innovation, such as the use of ICTbased information sources.

The adoption approach which is relevant for our purpose, describes the adoption decisions of users through the application of different individual and social decision making theories, such as the Actor Network Theory (Callon, 1999), Technology Acceptance Model (Davis, 1989), Theory of Reasoned Action (Ajzen and Fishbein, 1980), the Theory of Planned Behaviour 
(Ajzen, 1991) and the Unified Theory of Acceptance and Use of Technology (Venkatesh et al., 2003).

Other relevant theories include the Uses and Gratifications Theory (Lin 1999) which acknowledge goal orientation of users, who actively seek sources that meet their needs; and the social exchange theories, where clients use sources when social benefits due to using the information resource are greater than social costs, the information is relevant to needs and provides detailed individualized information. The Information Behaviour Model of Wilson (1999) is highly pertinent, which Ikoja-Odongo and Mostert (2006) benchmarked for improving our understanding about how people seek information. The Information Behaviour Model broadens our comprehension of circumstances that predict action by individuals when they seek information. Hence, information sources are considered vital components in the information-seeking domain.

From a pragmatic perspective, the design of good information services depends on adequate understanding of information needs and the challenges facing users when they seek information (Singh and Rani, 2013). In outlining the relationship between ICTs and socio-economic development, a number of factors including affordability, ability to use and content are necessary for any positive outcome. Heeks (2005) provided three models that improve our understanding of this relationship, namely, the Information Chain Model, Onion Ring Model and the Push and Pull Model.

The information chain model highlights the access barriers faced by ICT users, where resources are required in order to convert unprocessed data to useful information. These access barriers occur where resources are scarce, and are a considerable constraining factor in developing countries. The Onion Ring Model shows the various contributory factors that determine the success of ICT projects, and how local realities cannot be ignored. The model places considerable focus on context, in the initiation of development projects that utilise ICTs. The Push-and-Pull Model makes a case for balancing demand from target groups or end-users and the supply of ICT-based applications or interventions.

\section{A Review Framework}

Following the review of relevant theories and identification of associated concepts, a guiding framework for analysing the adoption of ICT-based market information sources among smallholder farmers in a particular farming system is presented in Figure 2. The framework 
enables the visualisation of relevant contributors that influence the ICT-adoption attributes among smallholder farmers, and assists in framing relevant questions or guide.

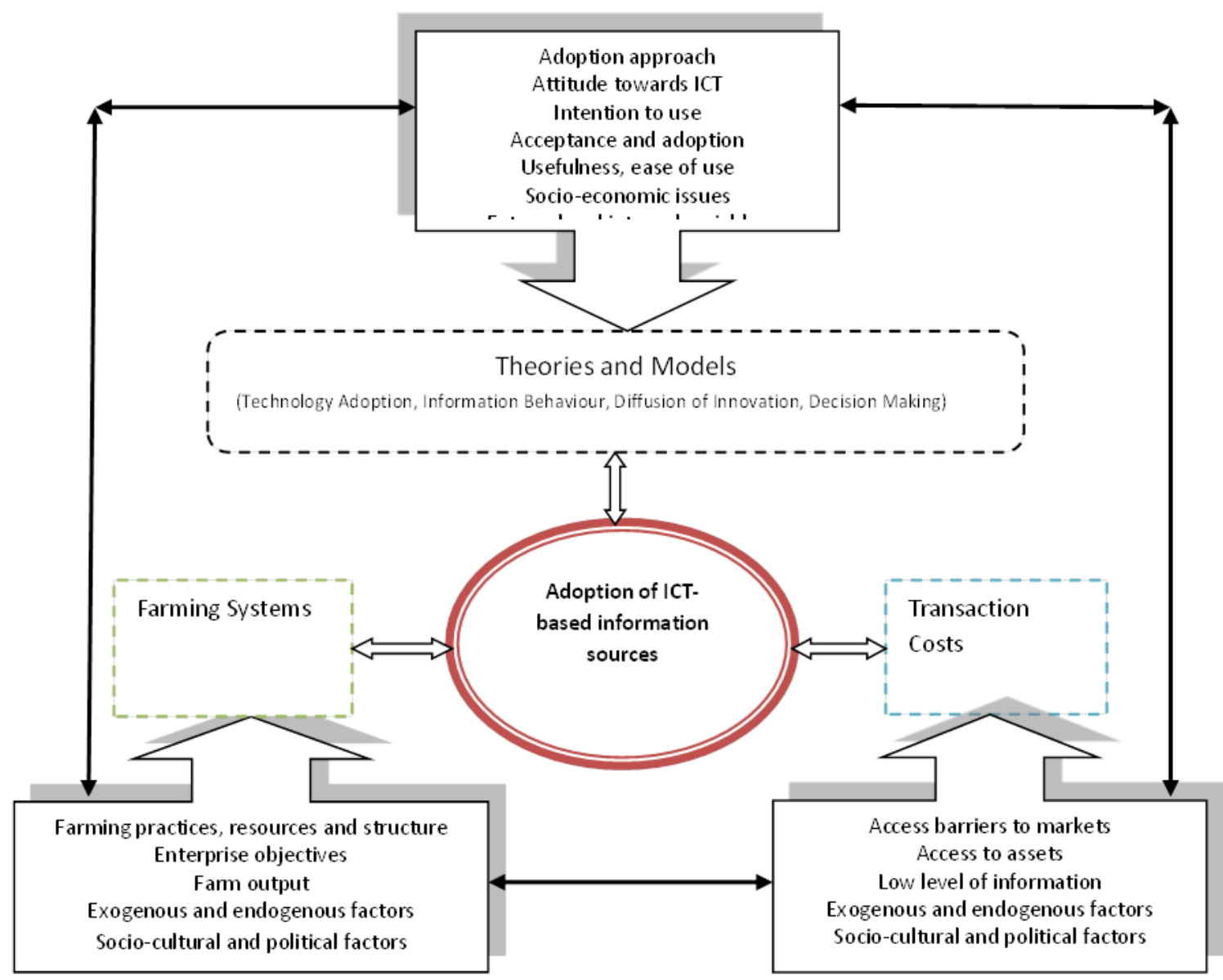

Figure 2. A framework to guide the review

In the framework shown in Figure 2, the smallholder farmer is influenced to adopt ICT-based market information sources by a number of factors. These factors can be understood within the three outlined theories, including the Unified Theory of Acceptance and Use of Technology, the Transaction Cost Theory and the Systems Theory. In order to adopt the technology, the smallholder farmer must have a positive attitude towards the technology and consider it beneficial for achieving the goals of the farm household, while the technology is easily used and socially valuable.

The purpose of the farm enterprise, household resources, farming practices and structure also play significant parts in the process of adopting the ICT-based information source for market participation. Finally, the adopting farmer has to overcome the access barriers for participating in markets, which includes distance to markets, poor rural infrastructure and transport systems, 
including inadequate information. In all these, the demographic characteristics of the farm household, social factors alongside other external variables affect the socio-economic environment within which the farmer operates, and invariably influences the outcome of the decision to adopt ICT-based market information sources for enhanced market participation.

\section{Existing Farmers' Information and Communication Technology Adoption Frameworks}

Mwakaje (2010) highlighted the major contribution of knowledge for enhancing production and marketing among smallholder producers. Various knowledge components determine the decisions made by rural farmers, and the framework provided depicts the impact of ICTs on market access and poverty reduction among rural farmers. The framework is relevant for evaluating the success or otherwise of information sources, though it places little relevance on the farmer and farm-specific characteristics. Its significance, however, is in how information types provide relevant answers to key questions pertinent to farmers' market participation. These questions include, who will buy, what volume required, the location of buyer and cost of transport. The feedback provided has significant effects on market participation and anticipated marketing outcomes for the farmer.

Mtega and Msungu (2013) articulated a modified framework which shows the role of information and communication technologies in the transformation of productivity in agriculture and also in poverty reduction, through the enhancement of access to agricultural information services. The framework was used in accessing the role, factors influencing use, and benefits accruable through the use of ICTs, and its contribution to improved livelihoods among farmers. From the framework, ICTs are enablers for integration of new and traditional knowledge systems, assist in building local capacities, and importantly for farmers, raising their profits from agriculture. Furthermore, the framework shows that for this to happen, certain constraints (enablers) need to be addressed, such as network and connectivity, applicable tariffs or fees, relevant ICT skills, and timing of programmes. The framework identified key outcomes from the deployment of ICTs which include improvements in local productivity and transformation in livelihood opportunities for those engaged in the agricultural sector.

Waqas et al. (2015) applied a framework indicating how the information sources used by livestock farmers are correlated to their socio-economic characteristics. They posited that the farmers' socio-economic characteristics have a significant relationship with the effectiveness of information sources. This ultimately affects the adoption of relevant technologies required 
for livestock production among farmers. In their framework used for determining the effectiveness of information sources among farmers, socio-economic characteristics such as age, education, family, source of income and nature of farming, links directly to both commercial purpose and livelihoods requirements of the farmers; and source of information used influences adoption of production technologies.

Magesa, Michael and Ko (2015) proposed a framework for accessing agricultural market information, and utilised a pro-poor, value chain approach. In their study which sought to examine an appropriate platform for connecting smallholder farmers to markets, there is an emphasis on the various bottlenecks faced by farmers in obtaining information and how these constraints can be removed. Key recommendations made include the improvement in physical infrastructure (such as roads and railway), provision and development of ICT related set-up, and collaboration with development partners to design relevant programmes that deliver market information to farmers. These imply a classic push-based intervention where efforts are made to deliver, rather than a farmer demand-based -or pull intervention. This framework is more or less, concerned with ensuring market access among smallholder farmers.

Langat, Litondo and Ntale (2016) also outlined a framework showing how intervening and moderating variables, determine the marketing decisions made by smallholder farmers. In their framework, ICT channels are independent and its attributes are linked with the choice of channel for market information. Their framework based on marketing models show ICTs are primarily utilized for improving the flow of market related information to smallholder farmers. This use of ICTs expands the scope of useful and accessible information available for smallholder producers, and enables their participation in various markets. The importance of this framework lies in recognizing how moderating and intervening variables shape the market decisions of smallholder farmers.

Benard and Dulle (2017) presented a modified framework adapted from Mtega and Benard (2013), to indicate how the use of ICTs contributes to communicating information and knowledge to specific communities. The framework linked various cultural, economic, infrastructural, social, individual and institutional variables necessary for the usage of rural information services. It indicates that the perceived usefulness of ICT tools among users is strongly influenced by cultural and socio-economic factors, as well as the availability of access points. The level of usage is hence influenced by both individual characteristics or circumstances (socio-economic factors, social capital and ownership of ICT resources) and 
possible welfare outcomes (institutional involvement, quality of information and knowledge). The importance of this framework lies in the division between intention (perceived usefulness) and behaviour (level of usage) among users, which in this review, is aligned to the information need (perceived usefulness) and information-seeking behaviour (level of usage) of farmers.

Lubua and Kyobe (2019) utilized a model for integrating socio-economic factors in their study of mobile phone adoption in agriculture. Using a multiple regression analysis, they established key relationships for the conceptual model which influenced the understanding of effect of predictor variables on the output variables, intention to use and rate of use. The framework presented a combination of variables which were integrated with socio-economic factors, to predict the use of an ICT-tool (mobile phones) among farmers in agriculture. The contribution of this study and its framework is the utilization of empirical data to confirm the important contribution made by socio-economic factors in the adoption of mobile phones in agriculture. This agrees with many other studies that empirically confirmed the significant influence of the socio-economic characteristics of farmers in their adoption of ICTs for marketing and production decisions in specific farming systems (Nwafor, 2019; Waqas et al., 2015; Oluwatayo, 2014; Kyem, 2012; Bagchi \& Udo, 2007).

\section{An Integrated Conceptual Framework of ICT-based Information Source Adoption}

Models are relevant in studying ICT adoption and have been widely utilized in the information systems and consumer behaviour research field. Lim et al. (2009) reported that Information Systems research was consolidated by the use of theories emanating from models. The generalization of empirical evidence in development of theories is an important channel for documenting our interpretation of the world. Constructs and their relationships may be a proposed model, and the development of a conceptual framework for smallholder farmer's ICT-based information source adoption attributes may be considered a contribution to theory development.

Within specific regions or geographic boundaries, many institutional factors and variables such as government regulation, availability of financial services, infrastructure, markets, among others; apply uniformly, providing similar conditions which as a distinguishing factor, may not be practical as the basis for a discerning framework. The proposed framework therefore places less emphasis on institutional variables, and highlights farmer and farm-specific features, or 
socio-economic characteristics, as central to understanding how individual smallholder farmers adopt ICT-based sources for obtaining market information.

The proposed emphasis on the socio-economic characteristics of farmers in ICT source use, as an influencing or independent variable is supported by key technology acceptance theories, and scholars such as Okello et al. (2014), Mwombe et al. (2013), Chirwa and Matita (2012), and Rahut et al. (2010). These authors submitted that important determinants of market participation and utilisation of ICTs relate to personal and farm-specific characteristics of farmers, and variables hypothesised to influence ICT use were selected among the personal features of farmer-respondents, such as their age, gender, level of education, farm size and income. These individual challenges are also highlighted by Fawole and Olajide (2012) as impeding factors in the adoption of ICTs among smallholder farmers. Worthy of note is the moderating effect of individual differences in a number of ICT adoption studies reported by Kim and Crowston (2011).

In support of this position, Hemmer et al. (2012) as well as Langat et al. (2016) established that the personal characteristics of information seekers influenced their selection and use of information sources. Furthermore, Mittal and Mehar (2015) reported that socio-economic factors were significantly associated with the information source relied upon by smallholder farmers; hence Olwande and Mathenge (2011), and Omiti et al. (2009), highlight the effect of socio-economic characteristics, which are utilised as independent or influencing variables in the ICT-source adoption research.

In their study of factors driving ICT adoption in both developing and developed countries, Bagchi and Udo (2007) found that economic development measured as GDP, income and inequality, education or training, and the availability of infrastructure had significant relationships with the adoption of ICTs. These factors can be classified into personal features, such as education and income, and institutional factors including infrastructure and government regulations.

The review also draws from elements of the Quadratic Usage Framework, which highlights internal factors related to the user such as competency and personal values, as directly influencing their ability and motivation, which results in the usage of technology. These attributes drawn from various fields of study and relevant theories outlined in Table 1 were applied to highlight the personal characteristics of smallholder farmers in the development of an applicable framework. 
Table 1. Contributions to developing an applicable framework for ICT-source adoption attributes

\begin{tabular}{|c|c|c|c|}
\hline Approach & Model Attributes & Theory / Model & Field of study \\
\hline Adoption & $\begin{array}{l}\text { - Personal features (age, gender, education, } \\
\text { - } \quad \text { Perital status, household size etc). } \\
\text { - Information search behaviour } \\
\text { - Intention based } \\
\text { - } \quad \begin{array}{l}\text { Major outcome variable influenced by various } \\
\text { independent variables }\end{array}\end{array}$ & $\begin{array}{ll}\text { - } & \text { Technology Acceptance } \\
\text { Models (Davis 1989). } \\
\text { - } \quad \text { Diffusion of Innovation } \\
\text { (Rogers 1995) } \\
\text { - } \quad \text { Quadratic Usage Framework } \\
\text { Marshall 2007; Mardis et al. } \\
\text { 2008) } \\
\text { - Principle of Least Effort (Zipf } \\
\text { 1949) } \\
\text { Acceptance and Use of } \\
\text { Technology (Venkatesh et al. } \\
\text { 2003) } \\
\text { Theory of Reasoned Action } \\
\text { (Ajzen \& Fishbein 1980) } \\
\text { Theory of Planned Behaviour } \\
\text { (Ajzen 1991) } \\
\text { Information Behaviour Model } \\
\text { (Wilson 1999) } \\
\text { Uses and Gratification Theory } \\
\text { (Lin 1999) }\end{array}$ & $\begin{array}{ll}\text { - } & \text { Information Systems } \\
\text { - } & \text { Information Studies } \\
\text { - } & \text { Social Psychology }\end{array}$ \\
\hline $\begin{array}{l}\text { Market \& } \\
\text { Rationality. }\end{array}$ & - $\quad$ Price, product and place & \begin{tabular}{lll} 
- & Consumer & \multicolumn{2}{c}{ Behaviour } \\
(Solomon 2006; Kotler \& \\
Keller 2006; Kotler \& \\
Armstrong 2013) \\
- Actor Network Theory (Callon \\
1999)
\end{tabular} & $\begin{array}{ll} & \text { Marketing } \\
\text { - } & \text { Consumer Science }\end{array}$ \\
\hline Utility & $\begin{array}{l}\text { - Use of Information Communication } \\
\text { Technology }\end{array}$ & $\begin{array}{l}\text { - } \begin{array}{l}\text { Transaction costs (Williamson } \\
1985)\end{array} \\
\text { - Uses and Gratification Theory } \\
\text { (Lin 1999) }\end{array}$ & - $\quad$ Economics \\
\hline $\begin{array}{l}\text { Farming } \\
\text { System }\end{array}$ & $\begin{array}{ll}\text { - } & \text { Household aspiration } \\
\text { - } & \text { Farmer characteristics } \\
\text { - } & \text { Farmer choices }\end{array}$ & $\begin{array}{l}\text { - } \quad \text { Systems Theory } \\
\text { (Norman et al. 1982; Norman } \\
\text { \& Matlon 2000) }\end{array}$ & $\begin{array}{ll}\text { - } & \text { Agriculture } \\
\text { - } & \text { Environmental Studies } \\
\text { - } & \text { Natural Resource } \\
& \text { Management }\end{array}$ \\
\hline
\end{tabular}

Smallholder farmers within a contiguous farming system face similar challenges or are affected by the same factors. The differentiating factor between adopters (users) or non-adopters (nonusers) of ICT-based market information sources can therefore be elucidated by the manner in which various external influences faced by all, are handled within an internal frame of preference by adopters. 
The framework specifically outlines the key variables which influence the adoption of ICTbased market information sources among smallholder farmers. These variables are conjectured to improve their use of ICT-based sources and continued participation in markets. In the framework outlined in Figure 3, the independent or explanatory variables consist of the personal, socio-capital and farm specific characteristics. These include age, gender, education level, income, farm size, income, membership of cooperative and household size.

Independent variables

Dependent variables

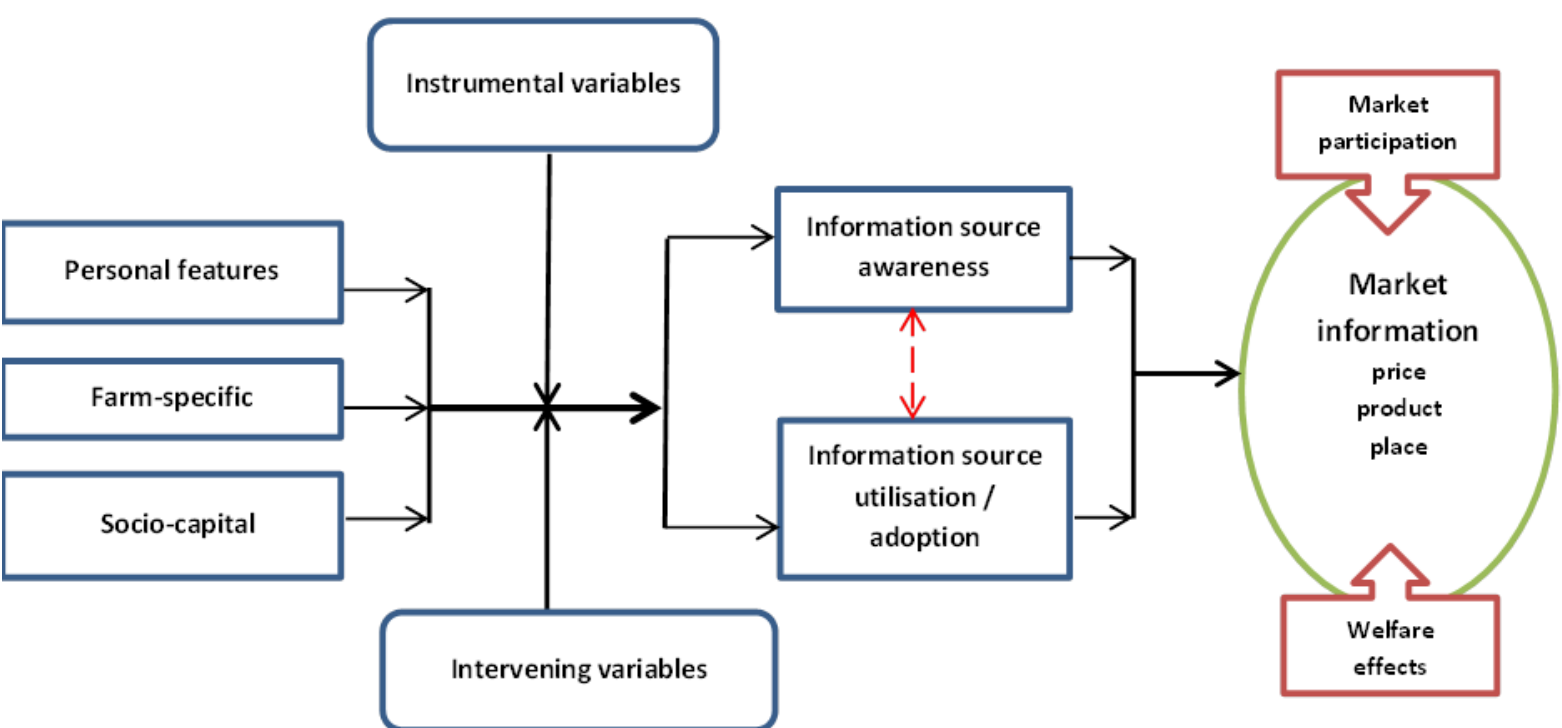

Figure 3. Proposed integrative framework of factors influencing farmers' ICT-based information source use.

These personal or farm specific features (independent or explanatory variables) are then combined with instrumental variables like cost, convenience, ease of use, availability and timeliness, farming system, infrastructure, network connection, government regulations; and intervening variables like need, knowledge and perception. As proposed by Msuya et al. (2014), the framework needs to accommodate the influence of many varying personal and environmental factors, which could be functional in different permutations and directions. The combined influences of these factors determine whether farmers are aware or use ICT-based market information sources, and what market information they are able to receive. The access to market information hence has consequences for smallholder farmers' participation or non- 
participation in markets, and other identified possible welfare outcomes such as poverty alleviation.

\section{CONCLUSION}

The review process developed a conceptual framework for identifying pertinent factors in the adoption of ICT-based information sources among smallholder farmers, especially in subSahara Africa. In the framework put out for peer-review and validation, the socio-economic characteristics of smallholder farmers such as their age, gender, level of education, membership of a cooperative, farm size, number of livestock owned, type of crop grown, an additional income source, among others, were posited as key variables in determining whether smallholder farmers in a farming system will adopt ICT-based information sources. Using a literature survey, pertinent studies related to adoption of ICTs, farmers' information source usage and relevant frameworks were identified, including applicable theories and models in technology adoption and information behaviour; all of which were used to construe the importance of personal features of smallholder farmers. It highlights the prevalent views, and support provided in the literature regarding the appropriateness of considering socio-economic features in adoption of ICT-based information sources among smallholder farmers.

Through identification of ICT-source adoption attributes among smallholder farmers, the framework demarcates the personal, socio-capital and farm-specific characteristics from other instrumental and intervening variables that apply uniformly to individual farmers within a farming system. When applied, the framework contributes to discern the prospects of adopting ICT-based information sources by individual farmers in the farming system. The possibility of identifying specific smallholder farmers, who are inclined to adopt a proposed ICT-based information source, provides an important tool for developing interventions which address the information needs of farmers. The framework may also be used to envisage related welfare outcomes and market participation pathways among smallholder farmers. 


\section{REFERENCE}

Acheampong L.D., Frimpong, B.N., Adu-Appiah, A., Asante, B.O. \& Asante, M.D. (2017). Assessing the information seeking behaviour and utilization of rice farmers in the Ejisu Juaben municipality of Ashanti Region of Ghana. Agriculture \& Food Security 6(1): 38-47

Adegbola, P. \& Gardebroek, C. (2007). The effect of information sources on technology adoption and modification decisions. Agricultural Economics 37(2007): 55-65.

Adereti, F.O., Fapojuwo, O.E. \& Onasanya, A.S. (2006). Information utilization on cocoa production techniques by farmers in Oluyole Local Government area of Oyo State, Nigeria. European Journal of Social Science 3(1): 1-7.

Adio, E.O., Abu, Y., Yusuf, S.K. \& Nansoh, S. (2016). Use of agricultural information sources and services by farmers for improve productivity in Kwara State. Library Philosophy and Practice (e-journal) Available at: http://digitalcommons.unl.edu/libphilprac/1456 Accessed on 23 July 2017.

Ajzen, I. \& Fishbein, M. (1980). Understanding Attributes and Predicting Social Behaviour. Englewood Cliffs, New Jersey: Prentice-Hall Publishers.

Ajzen, I. (1991). The Theory of Planned Behaviour. Organizational Behaviour and Human Processes 50(1): 179-211.

Ajzen, I. (2005). Attitudes, Personality and Behaviour Second edition. Berkshire: McGraw-Hill Education.

Ajzen, I. (2011). The theory of planned behaviour: Reactions and reflections. Psychology \& Health 26, pp. 1113-1127.

Agrilink. (2017). Agrilinks Multi-level Conceptual Framework. Agriculture Knowledge: Linking Farmers, Advisors and Researchers to Boost Innovation. Available at: https://www.agrilink2020.eu/wp-content/uploads/2019/02/AgriLink-conceptual-frameworkmain-report.pdf. Accessed on 9 November 2019.

Ali, J. \& Kumar, S. (2011). Information and communication technologies (ICTs) and farmers' decisionmaking across the agricultural supply chain. International Journal of Information Management 31(2): 149-159.

Alvarez, J. \& Nuthall, P. (2006). Adoption of computer based information systems: The case of dairy farmers in Canterbury, NZ, and Florida, Uruguay. Computers and Electronics in Agriculture 50(1): 48-60. 
Babu, S.C., Glendenning, C.J., Asenso-Okyere, K. \& Govindarajan, S.K. (2012). Farmer's information needs and search behaviors: Case study in Tamil Nadu, India. Discussion Paper No. 1165. March 2012. International Food Policy Research Institute (IFPRI).

Bagchi, K. \& Udo, G. (2007) Empirically testing factors that drive ICT adoption in Africa and OECD set of nations. Issues in Information Systems 8(2): 45-52.

Barrett, C. \& Carter, M. (2013). The economics of poverty traps and persistent poverty: empirical and policy implications. The Journal of Development Studies 49(7): 976-990.

Benard, R., Dulle, F. \& Lamtane, H. (2019). Challenges associated with the use of information and communication technologies in information sharing by fish farmers in the Southern highlands of Tanzania. Epub ahead of print. 26 October 2019. https://doi.org/10.1108/JICES-11-20180085 Accessed on 10 November 2019.

Benard, R. \& Dulle, F. (2017). Application of ICT tools in communicating information and knowledge to artisanal fishermen communities in Zanzibar. Knowledge Management \& E-Learning 9(2): 239-253.

Bitso, C. (2012). An Analysis of the Information Behaviour of Geography Teachers in a Developing African Country-Lesotho. Review of International Geography Education Online 2(1): 192-218.

Callon, M. (1999). Actor-Network Theory -The Market Test. In: Hassard, J. \& Law, J. (eds). ActorNetwork Theory and After. Oxford: Blackwell Publishers.

Chirwa, E.W. \& Matita, M. (2012). From subsistence to smallholder commercial farming in Malawi: A case of NASFAM commercialization initiatives. Future Agricultures, Working Paper 037. Available at: $\underline{w w w . f u t u r e s-a g r i c u l t u r e s . o r g ~ A c c e s s e d ~ o n ~} 10$ December 2018.

Davis, F.D. (1989). Perceived Usefulness, Perceived Ease of Use and User Acceptance of Technology. MIS Quarterly 13(3): 319-340.

Davis, F.D., Bogozzi, R.P. \& Warshaw, P.R. (1989). User acceptance of computer technology: A comparison of two theoretical models. Management Science 35(1): 982-1003.

Deloitte Consulting (2012). E-TransformAfrica. Agriculture Sector Study: Sector Assessment and Opportunities for ICT. Report by Deloitte Consulting. February 2012.

Fawole, O.P. (2006). Poultry farmers' utilization of information in Langelu local government area, Oyo State of Nigeria. International Journal of Poultry Science 5(5): 499-501. 
Fawole, O.P. \& Olajide, B.R. (2012). Awareness and Use of Information Communication Technologies by farmers in Oyo State, Nigeria. Journal of Agricultural \& Food Information 13(4): 326-337.

Ferris, S., Engoru, P. \& Kaganzi, E. (2008). Making Market Information Services Work Better for the Poor in Uganda. Report of Research Workshop on Collective Action and Market Access for Smallholders. Cali, Colombia.

Freeman, K. \& Mubichi, F. (2017). ICT use by smallholder farmers in rural Mozambique: a case study of two villages in Central Mozambique. Journal of Rural Social Sciences 32(2): 1-19.

GODAN (2018). Digital and data-driven agriculture: Harnessing the power of data for smallholders. GODAN Newsletter, May 2018. Global Open Data for Agriculture and Nutrition (GODAN), GFAR and CTA.

Gwaka, L.T. (2017). Digital Technologies and Sustainable Livestock Systems in Rural Communities. Electronic Journal of Information Systems in Developing Countries 81(6): 1-24.

Heeks, R. (2005). Foundations of ICTs in development. Available at: http://www.seed.manchester.ac.uk/medialibrary/IDPM/working-papers.pdf Accessed on 13 October 2018 .

Hemmer, E. \& Heinzl, A. (2012). Determinants of Information Channel Choice: The Impact of Task

Complexity and Dispositional Character Traits. Conference Paper. 45th Hawaii International Conference on System

Sciences.

Hill, M. (2009). Using farmer's information seeking behaviour to inform the design of extension. Extension Farming Systems Journal 5(2): 121-126.

Ikoja-Odongo, R. \& Mostert, J. (2006). Information seeking behaviour: A conceptual framework. South African Journal of Libraries \& Information Science 72(3): 145-158.

Ituma-Aleke, B. \& Egwu, P. (2014). Social Network Adaptation- a Panacea to Information and Communications Technologies (ICTs) Innovation Diffusion: The Case of Small-Scale Agribusinesses in Less Developed Countries. Available at: http://aisel.aisnet.org/ukais2014/55 Accessed on 21 November 2018.

Isaya, E.L., Agunga, R. \& Sanga, C.A. (2016). Sources of agricultural information for women farmers in Tanzania. Information Development 34(1): 77-89.

Israel, G. \& Wilson, K.M. (2006). Sources and Channels of Information Used by Educational Program Clients. Journal of Applied Communications 90(4): 55-78. 
Just, D., Wolf, S.A., Wu, S. \& Zilberman, D. (2002). Consumption of Economic Information in Agriculture. American Journal of Agricultural Economics 84(1): 39-52.

Kante, M., Oboko, R. \& Chepken, C. (2019). An ICT model for increased adoption of farm input information in developing countries: A case in Sikasso, Mali. Information Processing in Agriculture 6(1): 26-46.

Kapoor, S., Dwivedi, Y.K. \& Williams, M.D. (2013). Role of Innovation Attributes in explaining Adoption Intention for the Interbank Mobile Payment Service in an Indian context. In: Brooks, L., Wainwright, D., Wastell, D. (eds.) Social Information Systems. Oxford: UK Academy for Information Systems Proceedings 2013, pp. 203-220.

Kapoor, S. (2015). Use and Contribution of Information Sources in Buying Process of Agri-inputs by Farmers in India. Journal of Agricultural and Food information 16(2): 134-150.

Katengeza, S.P., Okello, J.J. \& Mensah, E.R. (2011). Factors influencing of awareness and use of electronic based market information services for farming business in Malawi. International Journal of Economic Research 2(4), 43-58.

Katengeza, S. (2012). ICT-based market information services, operational environment and performance: The Case of Malawi Agricultural Commodity Exchange and Food and Nutrition Security Joint Task Force. American International Journal of Social Science 1(2): 34-43.

Katengeza, S.P., Okello, J.J., Mensah, E.R. \& Jambo, N. (2014). Effect of Participation in ICT-Based Market Information Services on Transaction Costs and Household Income among Smallholder Farmers in Malawi. In: Bolay et al. (eds.) Technologies for Sustainable Development. Switzerland: Springer International Publishing

Khalil-Moghaddam, B. \& Khalia-Abadi, A. (2013). Factors affecting ICT adoption among rural users: A case study of ICT Center in Iran. Telecommunications Policy 37(11): 1083-1094.

Kiiza, B. \& Pederson, G. (2012). ICT-based market information and adoption of agricultural seed technologies: Insights from Uganda. Telecommunications Policy 36(4): 253-259.

Kim, Y. \& Crowston, K. (2011). Technology Adoption and Use Theory Review for Studying Scientists Continued Use of Cyber-infrastructure. Available at: http://crowston.syr.edu/system/files/ASIST2011.pdf. Accessed on 20 June 2018.

Kotler, P. \& Keller, K. (2006). Marketing Management. 12th Edition. Upper Saddle River: Prentice Hall. 
Kotler, P. \& Armstrong, G. (2013). Principles of Marketing. 15th Edition. Upper Saddle River: Prentice Hall.

Koyenikan, M..J. (2011). Extension Worker's Access to Climate Information and Services in Edo State, Nigeria. Scholars Research Library Archives of Applied Science Research 3(4): 11-20.

Kyem, P. \& Kwaku, A. (2012). Is ICT the Panacea to Sub-Saharan Africa's Development Problems? Rethinking Africa's Contentious Engagement with the Global Information Society. Progress in Development Studies 12(2): 231-244.

Langat, R., Litondo, K. \& Ntale, J. (2016). Information and Communication Technologies and Marketing Decisions among Small scale Farmers in Kenya: Review of Evidence. International Journal of Economics, Marketing and Management 4(4): 1167-1180.

Li, L. (2010). A critical review of technology acceptance literature. Southwest Decision Sciences Institute. Available at: http://www.swdsi.org/swdsi2010/PA104.pdf Accessed on 30 June 2018.

Lim, S., Saldanha, T., Malladi, S. \& Melville, N. (2009). Theories Used In Information Systems Research: Identifying Theory Networks in Leading IS Journals (2009). ICIS 2009 Proceedings. Available at: http://aisel.aisnet.org/icis2009/91 Accessed on 30 June 2018.

Lin, C.A. (1999). Uses and Gratifications. In: G. Stone, M. Singletary, and V. P. Richmond (eds.), Clarifying Communication Theories: A Hands-On Approach, Iowa: Iowa State University Press.

Lubua, E.W. \& Kyobe, M.E. (2019). The Influence of Socioeconomic Factors to the Use of Mobile Phones in the Agricultural Sector of Tanzania. The African Journal of Information Systems 11(4): 352-366.

Magesa, M., Michael, K. \& Ko, J. (2015). Towards A Framework For Accessing Agricultural Market Information. Electronic Journal of Information Systems in Developing Countries 66(3): 1-16.

Magesa, M., Michael, K. \& Ko, J. (2014). Agricultural Market Information Services in Developing Countries: A Review. Advances in Computer Science: an International Journal 3(3): 9-21.

Mahindarathne, M.G. \& Min, Q. (2018). Developing a model to explore the information seeking behaviour of farmers. Journal of Documentation 74(4): 781-803.

Manfre, C. \& Nordehn, C. (2013). Exploring the Promise of Information and Communication Technologies for Women Farmers in Kenya. Cultural Practice, LLC. MEAS Case Study No. 4. August 2013. 
Mardis, M., Hoffman, E. \& Marshall, T. (2008). A new framework for understanding educational digital library use: re-examining digital divides in US schools. International Journal on Digital Libraries 9(1): 19-27.

Martey, E. (2014). Market Information and Extent of Agricultural Commercialisation: Empirical Evidence from Smallholder Farmers in Effutu Municipality of Ghana. American Journal of Experimental Agriculture 4(12): 1680-1696.

MacVaugh, J. \& Schiavone, F. (2010). Limits to the diffusion of innovation: A literature review and integrative model. European Journal of Innovation Management 13(2): 197-221.

McBride, W.D. \& Daberkow, S.G. (2003). Information and the Adoption of Precision Farming Technologies. Journal of Agribusiness 21(1): 21-28.

Mittal, S. \& Mehar, M. (2015). Adoption of Modern Information and Communication Technology by Farmers in India: Analysis using Multivariate Probit Model. Journal of Agricultural Education and Extension 22(2): 1-14.

Msoffe, G. \& Ngulube, P. (2017). Information sources preference of poultry farmers in selected rural areas of Tanzania. Librarianship and Information Science 38(3): 265-271.

Msuya, C.P., Duvel, G.H. \& Rwambali, E.G. (2014). The Influence of Independent and Intervening Variables on Adoption of Recommended Maize Varieties in Tanzania. Tanzania Journal of Agricultural Sciences 13(1): 26-40.

Mtega, W. \& Benard, R. (2013). The state of rural information services in Tanzania: a meta-analysis. International Journal of Information and Communication Technology Research 3(2): 64-73.

Mtega, W.P. \& Msungu, A.C. (2013). Using information and communication technologies for enhancing the accessibility of agricultural information for improved agricultural production in Tanzania. Electronic Journal of Information Systems in Developing Countries 56(1): 1-14.

Mwakaje, A.G. (2010). Information and Communication Technology for Rural Farmers Market Access in Tanzania. Journal of Information Technology Impact 10(2): 111-128.

Mwombe, S., Mugivane, F., Adolwa, I. \& Nderitu, J. (2013). Evaluation of Information and Communication Technology Utilization by Smallholder Banana Farmers in Gatanga District, Kenya. The Journal of Agricultural Education and Extension 20(2): 247-261.

Norman, D. \& Matlon, P. (2000). Systems Research and Technical Change. In: E. Crawford and J. Collin (eds), Research on Agricultural Systems: Accomplishments, Perspectives and Methods, Huntinton: Nova Science Publishers. 
Norman, D., Simmons, E. \& Hays, H. (1982). Farming Systems in the Nigerian Savanna: Research and Strategies for Development. Boulder, Colorado: Westview Press.

Nwafor, C.U. (2019). Adoption of ICT-based Market Information Sources in Commercialising Smallholder Livestock Farming Systems: Case Study of Alfred Nzo District, Eastern Cape Province in South Africa. Unpublished Doctoral thesis. Central University of Technology, Bloemfontein-Free State, South Africa.

Ochieng, S.O., Okello, J.J. \& Otieno, D.J. (2013). Impact of ICT-based Market Information Services on Smallholder Farm Input Use and Productivity: The Case of Kenya. 4th International Conference of the African Association of Agricultural Economists. September 22-25. Hammamet-Tunisia.

Okello, J.J., Al-Hassan, R. \& Okello, R.M. (2010). A Framework for Analyzing the Role of ICT on Agricultural Commercialization and Household Food Security. International Journal of ICT Research and Development in Africa 1(1): 38-50.

Okello, J.J., Kirui, O.K., Gitonga, Z.M., Njiraini, W.G. \& Nzuma, J.M. (2014). Determinants of Awareness and Use ICT-Based Market Information Services in Developing Country Agriculture: The Case of Smallholder Farmers in Kenya. Quarterly Journal of International Agriculture 53(3): 263-282.

Oladele, O.I. (2011). Effect of Information Communication Technology on Agricultural Information Access among Researchers, Extension Agents, and Farmers in South Western Nigeria. Journal of Agricultural \& Food Information 12(2): 167-176.

Oluwatayo, I.B. (2014). Information and Communication Technologies as Drivers of Growth: Experience from Selected Small-Scale Businesses in Rural Southwest Nigeria. Spanish Journal of Rural Development 5(2): 65-76.

Olwande, J. \& Mathenge, M. (2011). Market participation among the poor rural households in Kenya. Policy Brief No. 42. Tegemeo Institute of Agricultural Policy and Development.

Omiti, J.M., Otieno, D.J., Nyanamba, O.T. \& McCullough, E. (2009). Factors influencing the Intensity of Market Participation by Smallholder farmers: A case of Rural and Peri-Urban Areas in Kenya. African Journal of Agricultural and Resource Economics 3(1): 57-82.

Opara, U.N. (2008). Agricultural Information Sources used by Farmers in Imo State, Nigeria. Information Development 24(4): 289 -295. 
Osei, S.K., Folitse, B.Y., Dzandu, L.P. \& Obeng-Koranteng, G. (2016). Sources of information for urban vegetable farmers in Accra, Ghana. Information Development. Epub ahead of print March 2016 DOI: 10.1177/0266666916638712.

Pimentel, P. \& Francisco, S. (2009). Initiatives for Development of Agricultural Information Management to Policy Makers: a Case Study from Mozambique. In: Opening Access to Agricultural Information and Knowledge: sharing the experience of the NARS. Accra, Ghana. 12-17 July, 2009.

Prakash, V. (2008). Some successful case studies from India. Linking Farmers to Market: Some Success Stories from Asia-Pacific Region. Available at: http://www.apaari.org/wpcontent/uploads/2009/05/ss_2008_01.pdf Accessed on 10 October 2018.

Raaij, E.M. \& Schepers, J.L. (2008). The acceptance and use of a virtual learning environment in China. Computers and Education 50(3): 838-852.

Rahut, D.B., Castellanos, I.V. \& Sahoo, P. (2010). Commercialization of Agriculture in the Himalayas. IDE Discussion Paper No. 265. Institute of Development Economics. December 2010.

Rogers, E.M. \& Shoemaker, F.F. (1971). Communication of Innovations: A Cross Cultural Approach. New York: The Free Press; London: Collier-Macmillan.

Rogers, E.M. (1995). Diffusion of Innovations. Fourth edition. New York: Free Press.

Sanusi, M.K., Omokhudu, A.C. \& Adeloye, F.F. (2018) Date Palm Farmers' Sources of Information in Dutse Local Government Area of Jigawa State, Nigeria. Journal of Agricultural \& Food Information 19(3): 272-283.

Sibande, I., Barley, A. \& Davidova, S. (2015). The impact of farm input subsidies on maize marketing in Malawi. International Conference of Agricultural Economists (ICAE), Milan-Italy, August $8-14$.

Simin, M. \& Jancovic, D. (2014). Applicability of Diffusion of Innovation Theory in Organic Agriculture. Economics of Agriculture 61(1): 517-531.

Singh, N. \& Rani, M. (2013). Information seeking behaviour of Faculty members of Chitkara University, Punjab: a case study. International Journal of Information Dissemination and Technology 3(2): 94-98.

Solomon, M. (2006). Consumer Behaviour: A European Perspective. 3rd edition. Harlow: Prentice Hall. 
Somers, S. \& Stapleton, L. (2013). e-Agricultural innovation using a human-centred systems lens, proposed conceptual framework. Artificial Intelligence \& Society 29(2): 193-202.

Sutherland, L.A. (2010). Environmental grants and regulations in strategic farm business decisionmaking: A case study of attitudinal behaviour in Scotland. Land Use Policy 27(1): 415-423.

Svensson, J. \& Yanagizawa, D. (2009). Getting Prices Right: The Impact of the Market Information Service in Uganda. Journal of the European Economic Association 7(2-3): 435-445.

Tembo, R. \& Maumbe. B. (2010). E-Agriculture Development in South Africa: Opportunities, Challenges and Prospects. E-Agriculture and E-Government for Global Policy Development: Implications and Future Directions. Available at: https://doi:10.4018/978-160566-8208.ch002 Accessed 13 October 2018.

Torero, M. (2011). A framework for linking small farmers to markets. Paper presented at the Conference, New Directions for Smallholder Agriculture. 24-25 January 2011. International Fund for Agricultural Development, Rome.

Velandia, M., Lambert, D.M., Jenkins, A., Roberts, R.K., Larson, J.A., English, B.C. \& Martin, S.W. (2009). Factors Influencing Selection of Information Sources by Cotton Producers Considering Adoption of Precision Agriculture Technologies. Presented at Agricultural \& Applied Economics Association Conference, Milwaukee, Wisconsin, July 26-29.

Venkatesh, V., Morris, M., Davis, G. \& Davis, S. (2003). User Acceptance of Information Technology: Towards a Unified View. MIS Quarterly 27(3): 425-478.

Waqas, A., Khan, A.K., Nosheen, F. \& Ahmad, M. (2015). Effectiveness of information sources regarding livestock production in Punjab, Pakistan. International Journal of Advanced Research in Biological Sciences 2(2): 7-13.

Wilson, T. (1999). Models in information behaviour research. Journal of Documentation 55(3): 249270.

Williamson, O.E. (1985). The economic institutions of capitalism: firms, markets and relational contracting. New York: The Free Press.

Woosley, J.M. \& Ashia, K. (2011). Comparison of Contemporary Technology Acceptance Models and Evaluation of the Best Fit for Health Industry Organizations. International Journal of Computer Science Engineering and Technology 1(11): 709-717.

World Bank (2011). e-Sourcebook: ICT in Agriculture- Connecting Smallholders to Knowledge, Networks and Institutions. Washington DC: The World Bank. 
Zoltner, J. \& Steffen, M. (2013). An assessment of market information systems in East Africa. Briefing Paper, USAID. Available at: https://d3a8pro7vhmx.cloudfront.net/eatradehub/pages/1134.pdf Accessed on 12 November 2017. 